\title{
Microbial protein synthesis in cattle given roughage-concentrate and all-concentrate diets: the use of 2,6-diaminopimelic acid, 2-aminoethylphosphonic acid and ${ }^{35} \mathbf{S}$ as markers
}

\author{
By F. G. WHITELAW, J. MARGARET EADIE, L. A. BRUCE \\ AND W. J. SHAND \\ Rowett Research Institute, Bucksburn, Aberdeen AB2 9SB
}

(Received 26 September 1983 - Accepted 16 March 1984)

\begin{abstract}
1. Three steers, each fitted with a rumen cannula and a re-entrant cannula in the proximal duodenum, were offered diets consisting of a barley-based concentrate and chopped hay at a daily intake of $61 \mathrm{~g} / \mathrm{kg}$ live weight ${ }^{0775}$ given in three equal meals. The ratio, concentrate: hay was changed from $50: 50$ to $90: 10$ and then to $100: 0$ in successive periods of 12-18 weeks and the flow and composition of digesta at the duodenum was measured over 48-h periods on each dietary treatment.

2. Samples of bacteria and protozoa were separated from rumen contents and the proportions of bacterial and protozoal nitrogen $(N)$ in duodenal digesta were estimated using 2,6-diaminopimelic acid (DAPA) and 2aminoethylphosphonic acid (AEP) as markers. On separate occasions, radioactive sulphur $\left({ }^{35} \mathrm{~S}\right.$ ) was infused into the rumen for $48 \mathrm{~h}$ and digesta collected over the final $24 \mathrm{~h}$; the specific radioactivity of $S$ in microbial and digesta fractions was used to estimate the proportions of microbial $\mathbf{N}$.

3. ${ }^{35} \mathrm{~S}$ gave reproducible and apparently reliable estimates of microbial protein formation: the proportion of microbial $\mathrm{N}$ in digesta was significantly higher $(P<0.05)$ for the 50:50 diet than for the other treatments but the energetic efficiency of microbial protein formation did not differ significantly between diets.

4. Estimates of bacterial $\mathrm{N}$ based on DAPA concentrations were highly variable and frequently impossibly high. It is suggested that many of the anomalous values were the result of non-representative sampling of the rumen microbial population and that this is particularly likely to occur when conditions within the rumen are unstable. AEP was found to be unsuitable as a marker for rumen protozoa as considerable concentrations of this substance were found also in rumen bacteria.
\end{abstract}

New methods for calculating the nitrogen requirements of ruminants (Agricultural Research Council, 1980) have focused attention on the need for reliable estimates of microbial protein synthesis in the rumen. Several techniques based on the use of chemical or radiochemical markers are now available for this purpose and their specific merits and limitations have been comprehensively reviewed in recent years (Smith, 1975; Tamminga, 1978; Stern \& Hoover, 1979). Although comparatively few direct comparisons have been made, studies in vivo (Walker \& Nader, 1975; Kennedy \& Milligan, 1978; Ling \& Buttery, 1978; Smith et al. 1978) and in vitro (Demeyer \& Van Nevel, 1976; Harmeyer et al. 1976) have shown that estimates of microbial protein formation obtained with different markers can differ quite widely. Even with individual marker methods there is often considerable variability both within and between animals (Dufva et al. 1982). Uncertainty exists also regarding the relative contributions made by the rumen bacteria and protozoa to the flow of microbial $\mathbf{N}$ at the duodenum, although evidence is accumulating that the ciliate protozoa may sequester in the rumen and may contribute considerably less to total $\mathrm{N}$ flow than their numbers in the rumen would indicate (Weller \& Pilgrim, 1974; Harrison et al. 1979; Leng, 1982; Steinhour et al. 1982).

The experiments described here formed part of a larger study designed to examine the flow of nutrients to the small intestine in cattle given diets containing various proportions of roughage and concentrate. Three separate marker techniques were used to estimate the extent of microbial protein synthesis in the rumen under each dietary regimen: these were the ${ }^{35}$ S-infusion method (Beever et al. 1974) which measures total microbial protein, the 
diaminopimelic (DAPA) method (Hutton et al. 1971) which measures bacterial protein and the aminoethylphosphonic acid (AEP) method which is claimed to be specific for protozoal protein (Abou Akkada et al. 1968; Hagemeister, 1975). Serious deficiencies in two of these methods became evident as the work progressed.

\section{MATERIALS AND METHODS}

Animals and diets. Three Friesian steers (nos. 347, 348 and 13) of mean initial live weight $245 \mathrm{~kg}$ were used. Each had been fitted, under anaesthesia, with a simple cannula in the rumen (McKenzie \& Kay, 1968) and a re-entrant cannula in the proximal duodenum (Brown et al. 1968) in separate operations approximately 6 weeks before the start of the experiment. The re-entrant cannulas were made of nylon and were situated about $80 \mathrm{~mm}$ beyond the pyloric sphincter.

The diet consisted of a medium-quality chopped hay ( $\mathrm{N}$ content, $14 \cdot 2 \mathrm{~g} / \mathrm{kg}$ dry matter (DM)) and a pelleted concentrate mixture ( $\mathrm{N}$ content, $25.6 \mathrm{~g} / \mathrm{kg} \mathrm{DM}$ ) containing $(\mathrm{g} / \mathrm{kg}) 850$ barley and 150 protein-mineral-vitamin supplement (Preston, 1963). Three different ratios for concentrate: hay, 50:50,90:10 and 100:0, were offered in sequence during successive periods of 18,12 and 12 weeks respectively. The daily intake of the complete diet was kept constant at $61 \mathrm{~g} / \mathrm{kg}$ live weight $\mathrm{t}^{0.75}$, adjusted weekly according to individual live weight, and was offered in three equal meals at $08.00,14.00$ and 20.00 hours.

Duodenal digesta collections. Collections of duodenal digesta were made over 48-h periods on each dietary treatment. In each animal, one collection was made on the $50: 50$ treatment and two collections, approximately 4 weeks apart, were made on each of the other treatments. Chromium sesquioxide impregnated on paper (Corbett et al. 1960) was used as a marker of digesta flow at the duodenum. Digesta was collected manually, essentially as described by Beever et al. (1971) except that collection intervals were of $1 \mathrm{~h}$ duration.

Isolation of bacteria and protozoa from rumen contents. Immediately after the end of each digesta collection period (11.00 hours) two large samples of rumen fluid (each approximately $800 \mathrm{ml}$ ) were taken for the isolation of samples of mixed bacteria and protozoa. After straining the rumen fluid through three layers of gauze the bacterial sample was obtained by differential centrifugation by a method similar to that described by Ibrahim et al. (1970). Each sample was examined microscopically for the presence of food particles or other debris and resuspension and centrifugation were continued until the samples were considered free of all contaminating materials.

The rumen ciliate protozoa were separated from rumen contents by an adaptation of the funnel method used by Eadie \& Oxford (1955). Ciliates which settled at the base of the funnel were run off into tubes containing the bicarbonate-phosphate buffer of Abou Akkada \& Howard (1960) and the organisms washed by decanting. This was repeated at intervals over the following $2-3 \mathrm{~h}$ in order to collect a representative sample of all sizes of ciliates. The collected samples were checked microscopically to ensure that they were still whole and active and that virtually all contaminating food particles and debris had been removed.

Bacterial and protozoal $N$ flows. Freeze-dried samples of bacteria and protozoa were analysed for DAPA and AEP respectively and these values together with the concentrations of DAPA and AEP in the corresponding digesta samples were used to estimate the relative contributions of bacterial and protozoal $\mathrm{N}$ to total $\mathrm{N}$ flow at the duodenum. In preliminary studies, samples of rumen bacteria harvested from ciliate-free cattle given an all-concentrate diet were examined for the presence of AEP. Similar observations were made on clarified rumen fluid $(40000 \mathrm{~g}$ for $30 \mathrm{~min})$ and dialysed rumen fluid (Hutton et al. 1971) obtained from a faunated sheep and on samples of the hay and barley concentrate portions of the diet. 
${ }^{35} \mathrm{~S}$ infusions. The relative proportions of food and microbial $\mathrm{N}$ in the digesta reaching the duodenum were measured by the ${ }^{35}$ S-infusion technique of Beever et al. (1974) as modified by Hume (1974). Each animal was examined once on each dietary treatment approximately 2 weeks after the first $48 \mathrm{~h}$ duodenal collection described previously. Solutions of $\mathrm{Na}_{2}{ }^{35} \mathrm{SO}_{4}(0.5 \mu \mathrm{Ci} / \mathrm{ml}, 40 \mathrm{ml} / \mathrm{h})$ were infused continuously into the rumen for $48 \mathrm{~h}$ and collections of duodenal digesta were made over the second $24 \mathrm{~h}$. As before, digesta was collected over $1 \mathrm{~h}$ intervals and representative portions of each hourly sample were bulked to give a composite $24 \mathrm{~h}$ sample. When the $90: 10$ diet was given, additional samples were bulked over $3 \mathrm{~h}$ intervals and analysed separately to provide information on changes in microbial protein formation throughout the $24 \mathrm{~h}$ feeding cycle. The proportion of microbial to total $\mathrm{N}$ in the duodenal digesta was obtained from the specific radioactivity ratio, counts $/ \mathrm{min}(\mathrm{cpm}){ }^{35} \mathrm{~S}$ per $\mu \mathrm{g} \mathrm{S}$ in whole digesta (D) : $\mathrm{cpm}^{35} \mathrm{~S}$ per $\mu \mathrm{g} \mathrm{S}$ in the microbial fraction (M) isolated from digesta (D:M ratio).

Rumen fluid volume and outflow. The volume of fluid in the reticulo-rumen and its rate of transfer to the omasum were measured in each animal on each dietary treatment. Polyethylene glycol (PEG) was used as the reference substance and was injected into the rumen on five successive days according to the procedures outlined by Hyden (1961). The daily dose was $75 \mathrm{~g}$ and samples of rumen fluid for PEG estimation were removed 1.5, 3, 6,12 and $24 \mathrm{~h}$ after dosing.

Rumen sampling. Samples of rumen fluid were taken from each animal at 11.00 hours on Mondays and Thursdays of each week throughout the experiment and at more frequent intervals at the times of duodenal-digesta collections and ${ }^{35} \mathrm{~S}$ infusions. Measurements were made of $\mathrm{pH}$, total and individual volatile fatty acids (VFA) and ammonia. Wet and fixed preparations of all samples were examined microscopically to assess the size and nature of ciliate populations and the morphological forms of bacteria. Gram films were also examined.

Analytical methods. The DM of duodenal-digesta samples and of microbial isolates was obtained by freeze-drying. Organic matter (OM) of all samples was derived by ashing in a muffle furnace at $560^{\circ}$ for $16 \mathrm{~h}$. Total $\mathrm{N}$ was measured by an automated $\mathrm{Kjeldahl}$ procedure (Davidson et al. 1970) and PEG in rumen fluid was estimated turbidimetrically using the gum-arabic reagent of Malawar \& Powell (1967).

Total VFA in rumen fluid was determined by steam distillation and the $\mathrm{C}_{2}-\mathrm{C}_{6}$ acids were separated by gas-liquid chromatography as described by Fell et al. (1968). Ammonia concentrations in rumen and duodenal fluids were measured by the method of Fawcett \& Scott (1960). DAPA and AEP in digesta samples and in bacterial and protozoal preparations were measured by the methods of Czerkawski (1974), with the hydrolysates being passed through an additional cation-exchange resin (Amberlite CG120; BDH Ltd, Poole, Dorset) to remove $\mathrm{Cr}_{2} \mathrm{O}_{3}$. Total $\mathrm{S}$ and ${ }^{35} \mathrm{~S}$ in digesta and microbial fractions were determined by the method of Bird \& Fountain (1970). Radioactivity was measured by liquid-scintillation counting (Packard Instrument Co. Ltd) using a commercial scintillation cocktail (NE 260; Nuclear Enterprises Ltd, Edinburgh).

\section{RESULTS}

Rumen fermentation patterns. Mean values for the concentrations and molar proportions of VFA and for rumen $\mathrm{pH}$ over the periods of duodenal digesta collections and ${ }^{35} \mathrm{~S}$ infusions are given for each dietary treatment in Table 1. Within treatment periods there was no evidence of any consistent change in fermentation indices between the days of $48 \mathrm{~h}$ duodenal collections and the days of ${ }^{35} \mathrm{~S}$ infusions. Only minor changes were seen in the molar proportions of VFA as the proportion of concentrates in the diet increased, although the 


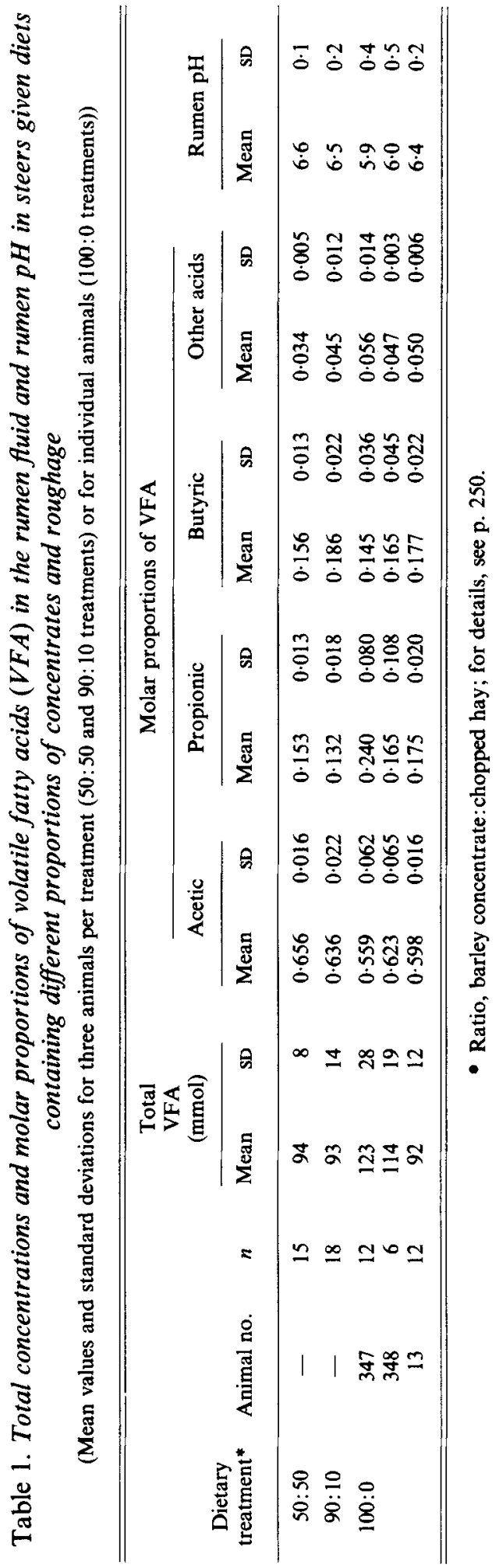


variability in the measurements showed a progressive increase with each change of diet, as shown by the SD values given in Table 1 . Much of this increased variability could be attributed to animals nos. 347 and 348, in which the change from the 50:50 to the $90: 10$ diet was accompanied by mild symptoms of bloat and frothing of rumen contents. In these two animals this condition recurred suddenly and at irregular intervals throughout the remainder of the experiment and, on the 100:0 treatment in particular, was often associated with fluctuations in the rumen fermentation pattern.

Animal no. 13, in contrast, never showed symptoms of bloat and maintained a stable rumen fermentation pattern at each stage of the experiment. The differences in variability between animal no. 13 and the other two animals were especially evident on the 100:0 diet and the mean and SD values for each rumen index on this dietary regimen have been presented separately for each animal in Table 1 . It is evident also from Table 1 that rumen $\mathrm{pH}$ tended to be lower and total VFA concentrations higher in the two animals exhibiting the greatest fluctuations in VFA proportions.

Microbiology of the rumen. All three animals showed a mixed, type B population of rumen ciliate protozoa (Eadie, 1967) throughout the experiment. As in previous studies (Eadie et al. 1970) the number of species present declined and Entodinium spp., Eremoplastron spp. and Epidinium spp. became predominant as the amount of barley concentrate in the diet increased. Large populations of ciliates were present in animals nos. 347 and 348 throughout the experiment, although occasional fluctuations in number occurred on the $90: 10$ and $100: 0$ treatments. Animal no. 13 consistently showed a smaller population of ciliates than the others but this remained remarkably stable on all dietary treatments.

The bacterial populations in the rumen were essentially similar to those described previously for animals changed from 50:50 diets to restricted intakes of all-concentrate diets, with Bacteroides spp. becoming the predominant organism as the proportion of concentrates increased (Eadie et al. 1970). In addition, however, the populations in the present animals showed frequent and marked fluctuations in the numbers of large tetracoci, particularly in animals nos. 347 and 348 when given the $90: 10$ and 100:0 diets. Increases in the numbers of these organisms often occurred without any specific change being noted in rumen $\mathrm{pH}$ or VFA pattern. They were, however, associated with an obvious thickening in the consistency of the rumen fluid and were frequently present during the episodes of frothing and bloating in animals nos. 347 and 348. As bloating also occurred in their absence, however, they cannot be identified as the causative organisms. Changes in the numbers of tetracocci and in the consistency of rumen fluid in these two animals coincided on several occasions with a $48 \mathrm{~h}$ duodenal collection.

Chains of organisms, believed to be Peptostreptococcus elsdenii, occasionally developed in large numbers and on one occasion (animal no. 348, 100:0 diet) these were associated with a fall in $\mathrm{pH}$, a reduction in ciliate numbers and a marked increase in the proportion of propionic acid in the rumen. This change in bacterial population and rumen conditions also coincided with a $48 \mathrm{~h}$ duodenal collection.

Rumen fluid volumes and outflow rates. Mean values for rumen fluid volumes and for outflow rates expressed both as a fractional clearance and a daily volume are given for each dietary treatment in Table 2. No significant differences were detected between treatments other than for total daily fluid outflow for which the value recorded for the 50:50 diet was significantly greater $(P<0.05)$ than for the other two diets.

Microbial $N$ flow at the duodenum, estimated by ${ }^{35} S$. The failure of an infusion pump resulted in the loss of one value for microbial $N$ flow on the 50:50 diet. Mean values for the proportion of microbial $N$ in total digesta $N(D: M$ ratio) for each dietary treatment are given in Table 3, together with values for the daily flow of $\mathbf{N}$ at the duodenum and the calculated values for daily microbial $\mathbf{N}$ flow. The calculated value for 'endogenous + 
Table 2. Rumen fluid volume, fractional clearance rate, daily fluid outflow and water intake in steers given diets containing different proportions of concentrates and roughage

(Mean values for three animals per treatment)

\begin{tabular}{lccccc}
\hline \hline Dietary treatment $\dagger$ & $50: 50$ & $90: 10$ & $100: 0$ & $\begin{array}{c}\text { Standard error } \\
\text { of } \\
\text { difference }\end{array}$ & $\begin{array}{c}\text { Statistical } \\
\text { significance } \\
\text { of difference }\end{array}$ \\
\hline Rumen fluid volume (1) & $27 \cdot 1$ & 22.8 & 23.8 & 3.4 & NS \\
Fractional clearance rate & 0.067 & 0.056 & 0.047 & 0.010 & NS \\
Daily fluid outflow (1) & 43.5 & 30.7 & 24.6 & 3.8 & NS \\
Water intake (l/d) & 11.5 & 11.4 & 10.6 & 1.5 & \\
\hline
\end{tabular}

NS, not significant.

* $P<0.05$.

+ Ratio, barley concentrate:chopped hay; for details, see p. 250 .

dietary' $\mathrm{N}$ flow, estimated as the difference between non-ammonia- $\mathrm{N}$ (NAN) flow and microbial $\mathrm{N}$ flow, is also given.

The proportion of microbial $\mathrm{N}$ in total digesta $\mathrm{N}$ was significantly greater for the $50: 50$ diet than for the other two treatments $(P<0.05)$ although there were no significant differences between treatments in the total daily flow of microbial $\mathrm{N}$ at the duodenum, calculated from this value and the corresponding values for total $\mathrm{N}$ flow. Over all treatments the mean flow of microbial $\mathrm{N}$ was $41 \cdot 8$ (SE 1.1) $\mathrm{g} / \mathrm{d}$. Measurements of $\mathrm{D}: \mathrm{M}$ ratio during successive $3 \mathrm{~h}$ intervals in three animals given the $90: 10$ diet indicated that there were no significant changes with time in the D:M ratio throughout the $24 \mathrm{~h}$ feeding cycle.

OM apparently digested in the rumen was somewhat lower on the $50: 50$ diet than on the others and this resulted in a slightly higher value for the calculated efficiency of microbial protein formation on this diet (Table 3). Overall, however, there were no significant differences between treatments and the mean value for this index was 22.7 (SE 1.1) g microbial $\mathrm{N} / \mathrm{kg}$ OM apparently digested in the rumen. Assuming that microbial $\mathrm{OM}$ contains approximately $100 \mathrm{~g} \mathrm{~N} / \mathrm{kg} \mathrm{DM}$, the corresponding value for microbial efficiency per kg OM 'truly' digested was 18.8 (SE $0 \cdot 7$ ), with again no significant difference between dietary treatments.

$D A P A$ as a marker of bacterial protein. The concentrations of DAPA in duodenal digesta and in the corresponding bacterial samples and the calculated contribution of bacterial $\mathrm{N}$ to the total flow of NAN at the duodenum are shown in Table 4. The range of values for these indices typically encountered in the literature is also given. DAPA values recorded here for the duodenal digesta samples were generally similar for all dietary treatments and were of the same order as values for digesta reported elsewhere. The bacterial samples, in contrast, were considerably more variable within each dietary treatment and this variability was much more marked on the $90: 10$ and $100: 0$ treatments than on the $50: 50$ mixture. The concentrations of DAPA in bacteria from the $90: 10$ and 100:0 treatments tended also to be low relative to other values recorded in the literature and, for animals nos. 347 and 348 , were frequently lower than the values obtained for the corresponding digesta samples. This obviously resulted in wholly impossible estimates of the contribution of bacterial $\mathbf{N}$ to total $\mathrm{N}$ flow at the duodenum in these animals on these particular diets. Overall, the only values for bacterial $N: N A N$ which were both consistent and realistic were those relating to the $50: 50$ dietary treatment.

$A E P$ as a marker of protozoal protein. As with the DAPA values, the concentrations of AEP in digesta and in the protozoa harvested from rumen contents showed considerable 
Microbial protein synthesis in cattle

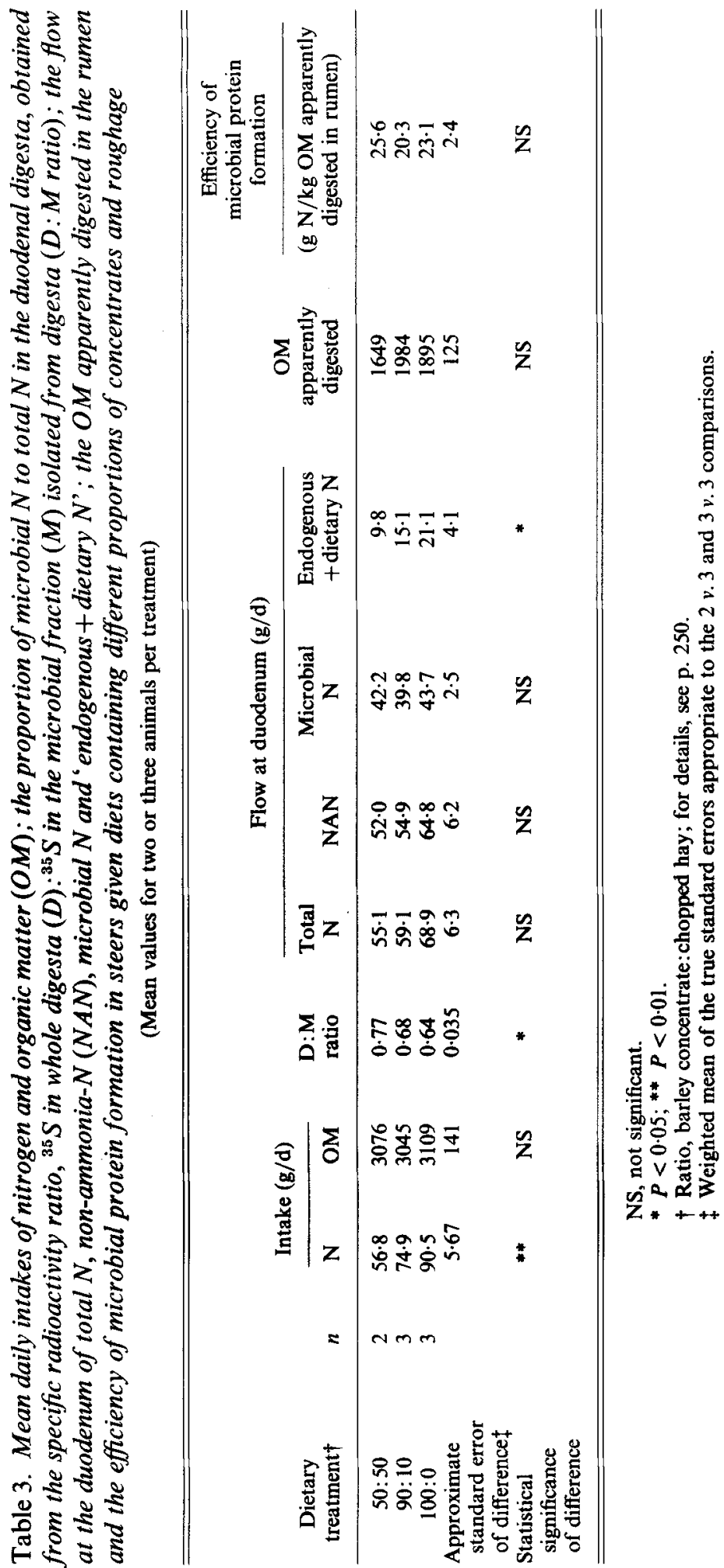


Table 4. Concentrations of diaminopimelic acid (DAPA) in duodenal digesta ( $\mathrm{mg} / \mathrm{g}$ nonammonia-nitrogen $(N A N)$ ) and in samples of rumen bacteria $(\mathrm{mg} / \mathrm{g} \mathrm{N})$ and the calculated contributions of bacterial $N$ to $N A N$ in digesta entering the duodenum of steers given diets containing different proportions of concentrates and roughage

\begin{tabular}{|c|c|c|c|c|c|}
\hline \multirow[b]{2}{*}{ Dietary treatment* } & \multirow[b]{2}{*}{ Animal no. } & \multirow[b]{2}{*}{$n$} & \multicolumn{2}{|c|}{ DAPA concentration } & \multirow{2}{*}{$\begin{array}{c}\text { Ratio, } \\
\text { bacterial N: NAN } \\
\text { in digesta }\end{array}$} \\
\hline & & & $\begin{array}{c}\text { Digesta } \\
\text { (mg/g NAN) }\end{array}$ & $\begin{array}{l}\text { Rumen bacteria } \\
\qquad(\mathrm{mg} / \mathrm{g} \mathrm{N})\end{array}$ & \\
\hline $50: 50$ & $\begin{array}{r}347 \\
348 \\
13\end{array}$ & $\begin{array}{l}1 \\
1 \\
1\end{array}$ & $\begin{array}{l}25 \cdot 3 \\
25 \cdot 0 \\
22 \cdot 7\end{array}$ & $\begin{array}{l}40 \cdot 4 \\
40 \cdot 2 \\
34 \cdot 4\end{array}$ & $\begin{array}{l}0.62 \\
0.62 \\
0.66\end{array}$ \\
\hline $90: 10$ & $\begin{array}{r}347 \\
348 \\
13\end{array}$ & $\begin{array}{l}2 \\
2 \\
2\end{array}$ & $\begin{array}{l}25 \cdot 4,33 \cdot 8 \\
31 \cdot 1,37 \cdot 3 \\
25 \cdot 1,24 \cdot 9\end{array}$ & $\begin{array}{l}25 \cdot 4,15 \cdot 0 \\
14 \cdot 6,11 \cdot 3 \\
29 \cdot 5,28 \cdot 8\end{array}$ & $\begin{array}{l}1 \cdot 00,2 \cdot 25 \\
2 \cdot 13,3 \cdot 30 \\
0 \cdot 85,0 \cdot 86\end{array}$ \\
\hline $100: 0$ & $\begin{array}{r}347 \\
348 \\
13\end{array}$ & $\begin{array}{l}2 \\
1 \\
2\end{array}$ & $\begin{array}{c}25 \cdot 3,30 \cdot 4 \\
33 \cdot 8 \\
17 \cdot 2,19 \cdot 0\end{array}$ & $\begin{array}{c}21 \cdot 4,18 \cdot 8 \\
60 \cdot 0 \\
25 \cdot 1,29 \cdot 8\end{array}$ & $\begin{array}{c}1 \cdot 18,1 \cdot 62 \\
0.56 \\
0.68,0.64\end{array}$ \\
\hline $\begin{array}{l}\text { Typical values recorded } \\
\text { in the literature } \\
\text { (see Smith, 1975) }\end{array}$ & & & 19-33 & $32-71$ & $0.50-0.73$ \\
\hline
\end{tabular}

* Ratio, barley concentrate:chopped hay; for details see p. 250 .

Table 5. Concentrations of 2-aminoethylphosphonic acid (AEP) in duodenal digesta ( $m g / g$ non-ammonia-nitrogen $(N A N)$ ) and in samples of ciliate protozoa isolated from rumen contents $(\mathrm{mg} / \mathrm{g} \mathrm{N})$ and the calculated contribution of protozoal $N$ to $\mathrm{NAN}$ in digesta entering the duodenum of steers given diets containing different proportions of concentrates and roughage

(Mean values with their standard deviations for three animals per treatment)

\begin{tabular}{|c|c|c|c|c|c|c|c|}
\hline \multirow[b]{3}{*}{ Dietary treatment ${ }^{*}$} & \multirow[b]{3}{*}{$n \dagger$} & \multicolumn{4}{|c|}{ AEP concentration } & \multirow{2}{*}{\multicolumn{2}{|c|}{$\begin{array}{c}\text { Ratio, } \\
\text { protozoal N: NAN } \\
\text { in digesta }\end{array}$}} \\
\hline & & \multicolumn{2}{|c|}{$\begin{array}{c}\text { Digesta } \\
\text { (mg/g NAN) }\end{array}$} & \multicolumn{2}{|c|}{$\begin{array}{l}\text { Protozoa } \\
(\mathrm{mg} / \mathrm{g} \mathrm{N})\end{array}$} & & \\
\hline & & Mean & SD & Mean & SD & Mean & SD \\
\hline $50: 50$ & 3 & 13.47 & $1 \cdot 18$ & $19 \cdot 76$ & $4 \cdot 55$ & 0.70 & $0 \cdot 10$ \\
\hline $90: 10$ & 6 & $11 \cdot 17$ & 1.87 & 23.79 & $2 \cdot 74$ & 0.48 & $0 \cdot 10$ \\
\hline $100: 0$ & 5 & $10 \cdot 76$ & 1.23 & $22 \cdot 12$ & $4 \cdot 82$ & 0.49 & 0.09 \\
\hline
\end{tabular}

* Ratio, barley concentrate:chopped hay; for details see p. 250.

† Total no. of samples examined within each treatment group.

variation (Table 5), although in this case the variability could not be related to specific animals or diets. No significant differences existed between the three dietary treatments in the AEP content of digesta or of ciliate protozoa. Overall, the estimated contributions of protozoal $\mathrm{N}$ to total NAN were characterized by high coefficients of variability and by mean values which appeared to be unrealistically high on all dietary treatments.

In the preliminary studies no AEP was detected in samples of clarified rumen fluid or in dialysed rumen fluid obtained from faunated sheep. Low concentrations of AEP $(0 \cdot 12$ and $0.18 \mathrm{mg} / \mathrm{g} \mathrm{N}$ ) were, however, present in two samples of rumen bacteria harvested from 
ciliate-free cattle given an all-concentrate diet. Significant amounts of AEP were detected also in the hay and barley-concentrate portions of the diet $(1.12$ and $0.98 \mathrm{mg} / \mathrm{g} \mathrm{N}$ respectively) and these could have contributed mean intakes of 62,74 and $89 \mathrm{mg}$ AEP daily on the $50: 50,90: 10$ and $100: 0$ treatments respectively. Allowing that this AEP might reach the duodenum unchanged, these dietary additions would have the effect of reducing the proportions of protozoal $\mathrm{N}$ in total NAN flow to $0.64,0.42$ and 0.42 on the $50: 50,90: 10$ and $100: 0$ treatments respectively.

\section{DISCUSSION}

The unstable rumen fermentation patterns which developed in two of the animals on the $90: 10$ and $100: 0$ dietary treatments were contrary to our previous experience and to our theories concerning the stability conferred on the rumen environment by the presence of large ciliate populations in cattle given all-concentrate diets (Whitelaw et al. 1970, 1972). We are fairly certain, however, that the unstable conditions in the present work were a consequence of the re-entrant cannulas at the duodenum and, more specifically, of the increasing incidence of blockage of the cannulas with digesta which occurred in animals nos. 347 and 348 as the experiment progressed. No serious difficulty with blockage was experienced in any of the animals when the high-roughage $(50: 50)$ diet was given and animal no. 13, which consistently showed more fluid rumen contents than the others, also had a low incidence of blockage on the 90:10 and 100:0 treatments. Evidence from the rumen-volume studies indicated that the presence of these cannulas might also have had a more generalized effect in depressing rumen outflow rates. Thus the mean fractional clearance rates in the present work were 0.067 for the 50:50 diet and 0.047 for the 100:0 diet (Table 2) whereas we have observed clearance rates of 0.116 and 0.059 respectively in previous studies in which these same diets were given to animals alike in every way to the present subjects apart from the presence of re-entrant cannulas (Eadie et al. 1970). Wenham \& Wyburn (1980) also concluded from radiographic studies that all types of intestinal cannulation caused some disruption to normal digesta flow in sheep but their observations unfortunately did not extend to rumen outflow rates nor to effects on rumen fermentation and rumen microbial populations.

\section{${ }^{35} S$ as a marker of microbial protein}

Ling \& Buttery (1978) reported experiments in which the three marker procedures used in the present work plus an additional method based on the RNA content of the rumen microbes were compared in sheep. They concluded, on the basis of the low coefficient of variation ( $\mathrm{CV} ; 2.6 \%)$ observed within dietary treatments, that the ${ }^{35} \mathrm{~S}$ method gave the most reproducible estimates of the proportion of microbial $\mathrm{N}$ in duodenal digesta and presented evidence to indicate that ${ }^{35} \mathrm{~S}$ probably also gave the most reliable estimates of this factor. In the present experiments the ${ }^{35} \mathrm{~S}$ method undoubtedly gave the most reproducible values although the variability in the measurements (CV 5.8\%) was greater than that observed by Ling \& Buttery (1978). This value, however, was achieved in the face of considerable instability in the rumen conditions of two of the animals examined and must be considered satisfactory. Indeed, it suggests that the incorporation of ${ }^{35} \mathrm{~S}$ by rumen microbes is both rapid and comprehensive and that the harvest of labelled bacteria at the duodenum provides a representative sample of the current rumen population.

The values reported here for the proportion of microbial $\mathrm{N}$ in total digesta $\mathrm{N}$ on all three treatments were within the range of values reported by Ling \& Buttery (1978) but, unlike their findings, the diets in the present experiments were not ranked in an order which was consistent with their estimated contents of rumen-degradable N (RDN). Thus the 50:50 
diet gave a significantly higher proportion of microbial protein in digesta than did either of the other treatments although the estimated ratio, RDN : metabolizable energy for this diet was 1.45 $\mathrm{g}$ RDN/MJ compared with 1.55 and $1.58 \mathrm{~g} / \mathrm{MJ}$ for the $90: 10$ and $100: 0$ diets respectively. By current standards, however, all these diets would provide adequate RDN for maximum microbial synthesis (Agricultural Research Council, 1980) and it is perhaps more likely that an increasing contribution of the relatively undegradable fish-meal protein to the total $\mathrm{N}$ flow at the duodenum on the $90: 10$ and 100:0 treatments was responsible for the observed effects. Soya-bean meal and fish meal $(2: 1)$ together made up 0.36 of total $\mathrm{N}$ in the barley-concentrate mixture and the calcuated intake of fish meal $\mathrm{N}$ increased from $4 \mathrm{~g} / \mathrm{d}$ on the $50: 50$ diet to $10 \mathrm{~g} / \mathrm{d}$ on the $100: 0$ diet.

\section{DAPA as a marker of bacterial protein}

The values reported by Ling \& Buttery (1978) for the DAPA content of bacterial samples showed considerable variation (CV 26.7\%) and the authors commented on the need to identify the source of these variations before this and similar marker systems can be applied with confidence. Recent investigations by Dufva et al. (1982) have shown that differences in DAPA concentrations exist between different species of rumen bacteria and that marked variations can occur between different dietary regimens and even between different animals on a given diet. Attempts to identify the sources of variability in the present work indicated that two animals were particularly implicated and that the anomalous ratios observed in these animals were related to extremely low values for the concentrations of DAPA in the isolates of rumen bacteria. Detailed examinations of formalin-fixed rumen samples indicated that these aberrant values were frequently associated with fluctuations in the numbers of large tetracocci in the rumen bacterial population. This organism was often seen in animals nos. 347 and 348 at the times of the duodenal digesta collections and a common sequence was for large numbers to be present during the first 12-24 $\mathrm{h}$ and for these to decrease considerably during the ensuing 24-48 h. Isolates of rumen bacteria made at the end of the collection period could thus contain a much smaller proportion of tetracocci than had been present in the rumen fluid and had contributed to digesta during the preceding $48 \mathrm{~h}$. Unfortunately, these tetracocci have not been isolated in culture from rumen material and nothing appears to be known of their DAPA content. In animal no. 13 the tetracocci were fewer in number and the bacterial population was considerably more stable during the digesta collection periods than in the other two animals. Thus in this animal, and in all three animals during the $50: 50$ feeding regimen, the bacterial samples isolated from the rumen were probably more representative of the bacteria present in the accumulated digesta samples.

The one very high value for DAPA in rumen bacteria, obtained in animal no. 348 on the 100:0 diet (Table 4), occurred on the occasion when very large numbers of Peptostreptococcus elsdenii were present in rumen fluid and tetracocci were reduced. Chains of $P$. elsdenii were seen in large numbers in the bacterial isolate from this animal but with other less-distinctive organisms it is usually extremely difficult to assess microscopically the proportionate make-up of a bacterial isolate obtained by high-speed centrifugation.

These suggestions regarding possible sources of error in the DAPA procedures are somewhat speculative since by no means all of the suspect values could be clearly related to changes in the rumen microbial populations. The evidence available, however, does confirm earlier suggestions that unrepresentative sampling of the rumen population can be a serious problem in marker techniques which require a microbial isolate for analysis (Nikolic \& Jovanovic, 1973; Smith, 1975; Tamminga, 1978; Stern \& Hoover, 1979). The present study indicates that this is likely to be a particular hazard with high-concentrate diets or in situations which give rise to unstable conditions within the rumen. 


\section{AEP as a marker of protozoal protein}

Ling \& Buttery (1978) calculated from AEP values that the proportion of $\mathrm{N}$ reaching the duodenum which was of protozoal origin ranged from 0.46 to 0.70 and these values they considered to be unrealistically high. Similar values were obtained in the present work, where the proportions ranged from 0.48 to 0.70 on the different treatments. Ling \& Buttery (1978) showed, however, that contrary to most reports in the literature (Abou Akkada et al. 1968; El-Shazly et al. 1975; Hagemeister, 1975), AEP was present in considerable concentrations in both dietary and bacterial material and could not therefore be used as a specific marker for protozoal protein. In the present experiments AEP was detected in both the hay and concentrate portions of the diets, but in much smaller amounts than reported by Ling \& Buttery (1978). Similarly, rumen bacteria from ciliate-free cattle were found to contain only traces of AEP. In an attempt to explain our findings, we have re-examined some of the bacterial samples obtained and have confirmed that these contained high concentrations of AEP: values ranging from 9.25 to $19.19 \mathrm{mg} \mathrm{AEP} / \mathrm{g} \mathrm{N}$ were found in four samples representing the three dietary treatments. These are considerably higher than the values reported by Ling \& Buttery (1978) which ranged from 1.9 to $9.7 \mathrm{mg} \mathrm{AEP} / \mathrm{g} \mathrm{N}$. Since AEP was absent from clarified rumen fluid (see p. 256) these findings suggest that the bacteria acquire AEP directly from dietary or protozoal material. The possibility remains, of course, that the isolated bacterial samples were contaminated with fragments of protozoal material but this we consider unlikely in view of the high concentrations of AEP observed and the rigorous microscopic examination to which all samples were subjected.

Of the three markers used to estimate microbial protein synthesis in the present study, only ${ }^{35} \mathrm{~S}$ gave sensible and reproducible results. Some of the results from DAPA were clearly nonsensical and the evidence that AEP may be present in rumen bacteria obviously negates its use as a marker for protozoa. In the absence of any other basis for comparison, the reliability of the results obtained by the use of ${ }^{35} \mathrm{~S}$ can only be adduced from their relationships with other indices of $\mathrm{N}$ and energy transformations within the digestive tract. The most useful index for this is probably the energetic efficiency of microbial protein formation, expressed in relation to OM disappearing anterior to the duodenum. The values for this index are given in Table 3 and are in good agreement with many estimates of microbial efficiency reported elsewhere (Smith, 1975; Czerkawski, 1978; Smith et al. 1978), although somewhat lower than the value of $30 \mathrm{~g} \mathrm{~N} / \mathrm{kg}$ OM apparently digested which has been adopted in the UK for calculating dietary protein requirements (Agricultural Research Council, 1980).

The authors wish to thank Dr R. N. B. Kay for the surgical preparation of the animals and $\mathrm{Mr} \mathrm{A}$. W. Boyne and Mr I. McDonald for assistance with the statistical analyses. They are indebted also to $\mathrm{Mr} \mathrm{M}$. Birnie for help with the duodenal digesta collections.

\section{REFERENCES}

Abou Akkada, A. R. \& Howard, B. H. (1960). Biochemical Journal 76, 445-451.

Abou Akkada, A. R., Messmer, D. A., Fina, L. R. \& Bartley, E. E. (1968). Journal of Dairy Science 51, 78-81. Agricultural Research Council (1980). Nutrient Requirements of Ruminant Livestock. Farnham Royal: Commonwealth Agricultural Bureaux.

Beever, D. E., Harrison, D. G., Thomson, D. J., Cammell, S. B. \& Osbourn, D. F. (1974). British Journal of Nutrition 32, 99-112.

Beever, D. E., Thomson, D. J., Pfeffer, E. \& Armstrong, D. G. (1971). British Journal of Nutrition 26, $123-134$. Bird, P. S. \& Fountain, R. D. (1970). Analyst 95, 98-102.

Brown, G. F., Armstrong, D. G. \& MacRae, J. C. (1968). British Veterinary Journal 124, 78-82.

Corbett, J. L., Greenhalgh, J. F. D., McDonald, I. \& Florence, E. (1960). British Journal of Nutrition 14, $289-299$. 
Czerkawski, J. W. (1974). Journal of the Science of Food and Agriculture 25, 45-55.

Czerkawski, J. W. (1978). Journal of Dairy Science 61, 1261-1 273.

Davidson, J., Mathieson, J. \& Boyne, A. W. (1970). Analyst 95, 181-193.

Demeyer, D. \& Van Nevel, C. J. (1976). Tracer Studies on Non-protein Nitrogen for Ruminants, vol. 3, pp. 63-68. Vienna: IAEA.

Dufva, G. S., Bartley, E. E., Arambel, M. J., Nagaraja, T. G., Dennis, S. M., Galitzer, S. J. \& Dayton, A. D. (1982). Journal of Dairy Science 65, 1754-1759.

Eadie, J. M. (1967). Journal of General Microbiology 49, 175-194.

Eadie, J. M., Hyldgaard-Jensen, J., Mann, S. O., Reid, R. S. \& Whitelaw, F. G. (1970). British Journal of Nutrition 24, 157-177.

Eadie, J. M. \& Oxford, A. E. (1955). Journal of General Microbiology 1, 298-310.

El-Shazly, K., Nour, A. M. \& Abou Akkada, A. R. (1975). Analyst 100, 263-268.

Fawcett, J. K. \& Scott, J. E. (1960). Journal of Clinical Pathology 13, 156-159.

Fell, B. F., Kay, M., Whitelaw, F. G. \& Boyne, R. (1968). Research in Veterinary Science 9, 458-466.

Hagemeister, H. (1975). Keiler Milchwirtschaftliche Forschungsberichte 27, 347-354.

Harmeyer, H., Holler, H., Martens, J. \& von Grabe, C. (1976). Tracer Studies on Non-protein Nitrogen for Ruminants, vol. 3, pp. 68-80. Vienna: IAEA.

Harrison, D. G., Beever, D. E. \& Osbourn, D. F. (1979), British Journal of Nutrition 41, 521-527.

Hume, I. D. (1974). Australian Journal of Agricultural Research 25, 155-165.

Hutton, K., Bailey, F. J. \& Annison, E. F. (1971). British Journal of Nutrition 25, 165-173.

Hyden, S. (1961). Kungliga Lantbrukhogskolans Annaler 27, 51-79.

Ibrahim, E. A., Ingalls, J. R. \& Bragg, D. B. (1970). Canadian Journal of Animal Science 50, 397-400.

Kennedy, P. M. \& Milligan, L. P. (1978). British Journal of Nutrition 39, 105-117.

Leng, R. A. (1982). British Journal of Nutrition 48, 399-415.

Ling, J. R. \& Buttery, P. J. (1978). British Journal of Nutrition 39, 165-179.

McKenzie, J. D. \& Kay, R. N. B. (1968). Journal of Science Technology 14, 15-16.

Malawar, S. J. \& Powell, D. P. (1967). Gastroenterology 53, 250-256.

Nikolic, J. A. \& Jovanovic, M. (1973). Journal of Agricultural Science, Cambridge 81, 1-7.

Preston, T. R. (1963). Veterinary Record 75, 1399-1402.

Smith, R. H. (1975). In Digestion and Metabolism in the Ruminant, pp. 399-415. [I. W. McDonald and A. C. I. Warner, editors]. Sydney: University of New England.

Smith, R. H., McAllan, A. B., Hewitt, D. \& Lewis, P. E. (1978). Journal of Agricultural Science, Cambridge 30, $557-568$.

Steinhour, W. D., Stokes, M. R., Clarke, J. H., Rogers, J. A., Davis, C. L. \& Nelson, D. R. (1982). British Journal of Nutrition 48, 417-431.

Stern, M. D. \& Hoover, W. H. (1979). Journal of Animal Science 49, 1590-1603.

Tamminga, S. (1978). In Ruminant Digestion and Feed Evaluation, pp. 5.1-5.13 [D. F. Osbourn, D. E. Beever and D. J. Thomson, editors]. London: Agricultural Research Council.

Walker, D. J. \& Nader, C. J. (1975). Australian Journal of Agricultural Research 26, 689-698.

Weller, R. A. \& Pilgrim, A. F. (1974). British Journal of Nutrition 32, 341-351.

Wenham, G. \& Wyburn, R. S. (1980). Journal of Agricultural Science, Cambridge 95, 539-546.

Whitelaw, F. G., Eadie, J. M., Mann, S. O. \& Reid, R. S. (1972). British Journal of Nutrition 27, 425-437.

Whitelaw, F. G., Hyldgaard-Jensen, J., Reid, R. S. \& Kay, M. G. (1970). British Journal of Nutrition 24, 179-195. 